\title{
PENGARUH PENAMBAHAN SERAT IJUK DAN TEMPURUNG KELAPA TERHADAP KUAT TEKAN BETON
}

\author{
Rudi Lubis dan M.H. Harahap*
}

Jurusan Fisika, Fakultas Matematika dan Ilmu Pengetahuan Alam, Universitas Negeri Medan, Indonesia

\begin{abstract}
Abstrak
Telah dilakukan penelitian geolistrik untuk menentukan batuan bawah permukaan di daerah Pamah Paku Kutambaru Kabupaten Langkat. Penelitian ini bertujuan untuk mengetahui jenis dan penyebaran batuan bawah permukaan berdasarkan nilai resistivitasnya di daerah Pamah Paku Kutambaru Kabupaten Langkat. Penentuan jenis batuan bawah permukaan dilakukan dengan menggunakan alat geolistrik ARES (Automatic Resistivity System) dengan metode Schlumberger sebanyak 12 lintasan dan panjang lintasannya 155 meter. Nilai resistivitas bawah permukaan diolah menggunakan software Res2Dinv didapatkan penampang dua dimensi. Penyebaran batuan dilakukan dengan menggunakan software surfer8 untuk mengetahui penyebarannya hingga kedalaman 28 meter. Hasil penelitian geolistrik menunjukkan terdapat batu gamping di kedalaman 15 meter hingga 28 meter dengan nilai resistivitas $500 \Omega \mathrm{m}$ hingga $10000 \Omega \mathrm{m}$. Dari permukaan hingga kedalaman 10 meter dengan nilai resistivitas antara $100 \Omega \mathrm{m}$ hingga $500 \Omega \mathrm{m}$ didominasi oleh batu tufa.
\end{abstract}

Kata Kunci: Pamah Paku, Geolistrik, Res2dinV, Surfer8, Batu gamping

How to Cite Rudi Lubis dan M.H. Harahap, (2015), Pengaruh Penambahan Serat Ijuk Dan Tempurung Kelapa Terhadap Kuat Tekan Beton, Jurnal Einsten Prodi Fisika FMIPA Unimed, 3 (2): 51-57.

\footnotetext{
*Corresponding author:

E-mail : rudilubis@yahoo.com
}

p-ISSN : I2338 - 1981 


\section{PENDAHULUAN}

Perkembangan teknologi dan
kemajuan industri yang semakin berkembang pesat memacu peningkatan pembangunan di segala sektor kehidupan, untuk itu harus senantiasa diimbangi dengan perkembangan Industri dalam berbagai bidang produksi. Upaya peningkatan kualitas dan mutu hasil produksi, baik Industri besar maupun Industri rumah tangga (home industri) terus diupayakan. Seiring dengan hal tersebut maka tuntutan akan mutu dan kualitas produksi dihasilkan semakin meningkat pula (Supatmi, 2011).

Hal lain yang mendasari pemilihan dan penggunaan beton sebagai bahan konstruksi adalah faktor efektifitas dan tingkat efisiensinya. Secara umum bahan pengisi (filler) beton terbuat dari bahanbahan yang mudah diperoleh, mudah diolah (workability) dan mempunyai keawetan (durability) serta kekuatan (strength) yang sangat diperlukan dalam suatu konstruksi. Dari sifat yang dimiliki beton itulah menjadikan beton sebagai bahan alternative untuk dikembangkan baik bentuk fisik maupun metode pelaksanaannya. Menurut Tjokrodimuljo (1996), kuat tekan beton akan ikut meningkat apabila serat yang digunakan mempunyai modulus elastisitas lebih tinggi daripada beton.

Dari bermacam-macam bahan serat tersebut, serat baja merupakan yang paling sering digunakan baik untuk penelitian maupun dalam aplikasinya, karena modulus elastisitasnya lebih tinggi daripada beton. Sehingga selain kuat tariknya yang mengalami peningkatan, kuat tekannya pun akan meningkat. Menurut Tjokrodimuljo (1996) bahan serat bisa berupa asbestos, gelas/kaca, plastik, baja atau serat tumbuhan (rami, ijuk, bambu, sabut kelapa). Terkadang pada daerah tertentu sangat sulit untuk mendapatkan agregat, khususnya agregat kasar dan agregat halus sebagai bahan utama dalam pembuatan beton. Untuk mengatasi hal tersebut, maka penulis melakukan penelitian ini dengan menggunakan tempurung kelapa sebagai penambahan agregat kasar dan selain dari pasir agregat halusnya di tambahi dengan serat ijuk dalam pembuatan beton. Bertolak dari kenyataan yang terjadi, pemanfaatan serat ijuk sebagai bahan tambahan dalam campuran beton memiliki prospek yang sangat baik di masa depan.

Beton ringan adalah beton yang memiliki berat volume lebih ringan dari pada beton pada umumnya. Jika pada beton konvensional/umum mempunyai berat volume $2400 \mathrm{~kg} / \mathrm{m} 3$, berdasarkan SNI beton ringan mempunyai berat volume mulai $1400-1850 \mathrm{~kg} / \mathrm{m} 3$. Beton ringan pada umumnya memiliki campuran yang sama dengan beton normal, hanya saja agregat kasar pada beton ringan perlu dikurangi berat jenisnya, sesuai dengan kelas kuat tekannya (ASTM C1693-11). Sejarah perkembangan beton ringan di Indonesia memiliki babakan tersendiri. Pertama kali mulai dikenal sejak tahun 1995, saat didirikannya PT Hebel Indonesia di Karawang Timur. (http://wijoseno.wordpress.com/2008/09/ 22/beton-ringan/). Kemudian, berbagai macam penelitian dilakukan untuk memperoleh hasil beton ringan yang lebih baik.

Dari beberapa penelitian mengenai penambahan tempurung kelapa terhadap kuat tekan beton didapatkan dalam penelitian Rustendi, I (2004) dengan pemanfaatan tempurung kelapa sebagai material serat terhadap kuat tekan dan kuat tarik beton bahwa penambahan serat tempurung kelapa pada adukan beton akan menurunkan kuat tekannya. 10\%, dan $15 \%$ persentase terbesar memberikan efek terbesar pula. Menurut Suarnita (2010) pada penelitiannya Fraksi volume agregat ringan tempurung kelapa yang digunakan adalah 0.35 , faktor air semen (FAS) adalah sebesar 0.5 serta pengujian benda uji dilakukan pada umur 28 hari. diperoleh nilai rata-rata dari karakteristik beton ringan tempurung kelapa meliputi nilai berat isi rata-rata yaitu $1.701 \mathrm{~kg} / \mathrm{m}^{3}$, nilai kuat tekan rata-rata yaitu $14.054 \mathrm{MPa}$, nilai modulus elastisitas $\left(\mathrm{E}_{\mathrm{c}}\right)$ yang diperoleh dari 
kemiringan garis pada kurva elastis (0.5 $f^{\prime} c$ ) yaitu $4595.590 \mathrm{MPa}$, nilai kuat tarik belah rata-rata yaitu $1.713 \mathrm{MPa}$, kuat lentur rata-rata yaitu $2.329 \mathrm{MPa}$, dan kuat lekat tulangan rata-rata dengan menggunakan tulangan ulir $\varnothing 8.8 \mathrm{~mm}$ yaitu $10.308 \mathrm{MPa}$.

Akbar, F, dkk, (2013) telah meneliti mengenai penggunaan tempurung kelapa terhadap beton dimana tempurung yang digunakan dimensinya lebih kecil, yaitu maksimal $15 \mathrm{~mm}$. Dan yang di hasilkan dari penelitian ini karakteristik beton campuran tempurung kelapa berdasarkan hasil kuat tekan beton K-100 pada umur 7 hari perawatan dapat meningkat dengan penambahan 5\% tempurung kelapa yaitu sebesar 16,5 Ton atau 73,33 $\mathrm{Kg} / \mathrm{Cm}^{2}$ dengan proyeksi kekuatan pada umur 28 hari sebesar $112,82 \mathrm{Kg} / \mathrm{Cm}^{2}$.

Nelly Wahyuni, (2010) Beton dengan menggunakan campuran berupa serat ijuk pendek dibuat dengan waktu perendaman selama 28 hari. Pengujian sifat mekanik dan sifat fisik benda uji: kuat tekan, kerapatan, dan penyerapan air sudah sesuai dengan standar ASTM dan SNI. Komposisi serat dengan variasi $0 \%, 2,5 \%$, $5 \%, 7,5 \%$, dan $10 \%$. Hasil penelitian menunjukkan bahwa beton dengan variasi komposisi terbaik adalah $2,5 \%$ serat ijuk pendek. Pada pengujian diperoleh haasil kuat tekan yaitu $7,02 \mathrm{MPa}-25,61 \mathrm{MPa}$, kerapatan $2,10 \mathrm{gr} / \mathrm{cm}^{3}-2,32 \mathrm{gr} / \mathrm{cm}^{3}$, dan penyerapan air $1,5 \%-3,5 \%$.

Sedangkan penambahan serat ijuk terhadap kuat tarik beton didapatkan dari penelitian Sarjono dan Wahjono (2008) dalam penelitiannya di dapatkan hasil bahwa serat ijuk sebanyak (1-5) pada campuran semen- pasir mampu meningkatkan kuat tarik belah dengan peningkatan kuat tarik tertinggi di capai oleh penambahan ijuk sebanyak 4 yaitu sebesar 34,81 dan peningkatan kuat desak tertinggi di capai oleh penambahan ijuk sebanyak 4 sebesar 9,86 dan peningkatan ketahan kejut.

Penggunaan jerami padi untuk beton ringan telah dilakukan Siswanto dan Sumarni (2012) didapatkan hasil dari penelitian ini adalah berat jenis batako dengan pintalan jerami lebih ringan 17,3\% daripada batako biasa, kuat tekan untuk batako biasa didapat sekitar 732,6 $\mathrm{MPa}$, sedangkan kuat tekan batako dengan jerami 2,169 MPa.

Menurut Supatmi, (2011) berat jenis pasir ialah rasio antara massa padat pasir dan massa air dengan volume dan suhu yang sama. Berat jenis pasir dari suatu agregat normal adalah 2,5-2,7 $\mathrm{gr} / \mathrm{cm}^{3}$; berat jenis pasir dari agregat berat adalah lebih dari 2,8 $\mathrm{gr} / \mathrm{cm}^{3}$ dan berat jenis pasir dari agregat ringan adalah kurang dari 2,0 $\mathrm{gr} / \mathrm{cm}^{3}$. Dalam penelitian ini, adapun komposisi untuk pembuatan beton itu sendiri yaitu pasir, serat ijuk, tempurung kelapa (pengganti agregat kasar, semen dan air.

Imam munandar, dkk. (2010) hasil penelitian didapatkan bahwa semakin kecil diameter serat, maka kekuatan tariknya semakin tinggi. Kekuatan tarik terbesar pada kelompok serat ijuk berdiameter kecil (0.25-0.35 mm) adalah sebesar 208.22 Mpa, regangan 0.192, modulus elastisitas 5.37Gpa dibandingkan kelompok serat iujuk dengan diameter besar (0.45-0.55 $\mathrm{mm}$ ) sebesar $198.15 \mathrm{Mpa}$, regangan 0.37, modulus elastisitas 2.84 Gpa. Hal ini dikarenakan rongga pada serat berdiameter 0.46-0.55 lebih besar dibandingkan serat berdiameter $0.25-0.35 \mathrm{~mm}$.

Robby Gunawan ,dkk.(2008) Pengujian menghasilkan kuat tekan beton normal pada umur 28 hari sebesar $227,17 \mathrm{~kg} / \mathrm{cm}^{2}$ atau 23,18 MPa. Pada penambahan serat ijuk 0,25\% pada umur 28 hari kuat tekannya sebesar 238,22 $\mathrm{kg} / \mathrm{cm}^{2}$ atau 24,30 MPa (lebih besar 4,9\% dari beton normal). Dengan tambahan serat ijuk $0,50 \%$ pada 28 hari kuat tekannya sebesar $243,31 \mathrm{~kg} / \mathrm{cm}^{2}$ atau 24,82 MPa (lebih besar 7,2 $\%$ dari beton normal). Dengan tambahan serat ijuk $1 \%$ pada umur 28 hari kuat tekannya sebasar 241,61 kg/cm ${ }^{2}$ atau 24,65 MPa (lebih besar $6,4 \%$ dari beton normal). Penambahan $0,50 \%$ serat ijuk menghasilkan nilai kuat tekan yang maksimal sebesar $243,31 \mathrm{~kg} / \mathrm{cm}^{2}$ atau 24,82 $\mathrm{MPa}$, lebih tinggi dari beton normal yang hanya mencapai $227,17 \mathrm{~kg} / \mathrm{cm}^{2}$ atau $23,18 \mathrm{Mpa}$ pada umur beton 28 hari, hasil penelitian ini 
secara umum dapat disimpulkan bahwa, beton dengan bahan tambah serat ijuk mempunyai kualitas fisik yang baik sehingga bisa digunakan sebagai bahan tambahan dalam campuran beton untuk meningkatkan kuat tekan beton. hasil penelitian bahwa beton menggunakan bahan tambah serat ijuk dengan varian ijuk $0,25 \%$ menghasilkan nilai kuat tekan beton pada umur 28 hari sebesar 238,22 $\mathrm{kg} /$ atau 24,30 Mpa lebih besar dari pada beton normal yang menghasilkan kuat tekan beton sebesar 227,17 kg/ atau 23,18 Mpa (lebih besar $4,9 \%$ dari beton normal).

Membedakan penelitian ini dengan penelitian terdahulu yang pernah dilakukan adalah pada penelitian ini serpihan serat tempurung kelapa yang digunakan dimensinya lebih kecil lagi, yaitu maksimal $10 \mathrm{~mm}$ agar dapat meminimalisir tereliminasinya massa/volume beton akibat penambahan tempurung tersebut, selain itu dengan dimensi yang lebih kecil pecahan tempurung kelapa dapat bekerja lebih sempurna sebagai filler (bahan pengisi). Variasi campuran yang direncanakan yaitu serat ijuk 4, 6, 8 dan 3, 4, 5 tempurung kelapa.

\section{METODE PENELITIAN}

Penelitian ini akan dilakukan di Laboratorium Teknik Sipil USU pada bulan April sampai Juni 2014. Bahan-bahan yang digunakan dalam penelitian ini yaitu sebagai berikut :

1. emen Portland Tipe I

2.

$$
\text { S }
$$

gregat Halus (Pasir sungai)

Pasir sungai yang merupakan pasir yang terdapat di sungai

3.

A

gregat kasar berupa tempurung kelapa

4.

ir dengan nilai FAS 0,5

5.

li kotor

6.

erat Ijuk

Pada penelitian ini digunakan standart ASTM untuk mendesain campuran beton.pada penelitian ini digunakan campuran beton dengan mutu K-175. Tabel 1. memperlihatkan komposisi campuran yang telah disesuaikan dengan standart ASTM. Tabel 2. memperlihatkan komposisi campuran untuk berbagai variasi tambahan tempurung kelapa dan serat ijuk.

Tabel 1. Komposisi Adukan Beton Rencana dengan Agregat

\begin{tabular}{|l|l|l|}
\hline $\begin{array}{l}\text { Nama } \\
\text { Bahan }\end{array}$ & $\begin{array}{l}\text { Massa/Volume } \\
\mathrm{kg} /\end{array}$ & Perbandingan \\
\hline Semen & 367,4 & 1 \\
\hline Pasir & 720,5 & 2 \\
\hline Kerikil & 1127 & 3 \\
\hline Air & 185 & 0,5 \\
\hline
\end{tabular}

Tabel 3.4 Perbandingan Agregat Pada Setiap Sampel

\begin{tabular}{|c|c|c|c|c|c|c|}
\hline $\begin{array}{l}\text { Kode } \\
\text { sample }\end{array}$ & $\begin{array}{l}\text { Air } \\
(\mathrm{Kg})\end{array}$ & $\begin{array}{l}\text { Pasir } \\
(\mathrm{Kg})\end{array}$ & $\begin{array}{l}\text { Kerikil } \\
(\mathrm{Kg})\end{array}$ & $\begin{array}{l}\text { Tempurung } \\
\text { kelapa }(\mathrm{Kg})\end{array}$ & $\begin{array}{l}\text { Semen } \\
(\mathrm{Kg})\end{array}$ & $\begin{array}{l}\text { Serat } \\
\text { Ijuk } \\
(\mathrm{Kg})\end{array}$ \\
\hline A & 2,24 & 8,97 & 13,45 & - & 4,48 & - \\
\hline \multirow{3}{*}{ B } & 2,24 & 8,97 & 12,11 & 1,34 & 4,39 & 0,089 \\
\hline & 2,24 & 8,97 & 12,11 & 1,34 & 4,34 & 0,134 \\
\hline & 2,24 & 8,97 & 12,11 & 1,34 & 4,30 & 0,179 \\
\hline \multirow{3}{*}{$\mathrm{C}$} & 2,24 & 8,97 & 10,76 & 2,69 & 4,39 & 0,089 \\
\hline & 2,24 & 8,97 & 10,76 & 2,69 & 4,39 & 0,134 \\
\hline & 2,24 & 8,97 & 10,76 & 2,69 & 4,34 & 0,179 \\
\hline \multirow{3}{*}{ D } & 2,24 & 8,97 & 9,42 & 4,01 & 4,39 & 0,089 \\
\hline & 2,24 & 8,97 & 9,42 & 4,01 & 4,34 & 0,176 \\
\hline & 2,24 & 8,97 & 9,42 & 4,01 & 4,30 & 0,179 \\
\hline
\end{tabular}

Diagram alir penelitian ini ditunjukkan pada gambar berikut 
Gambar 1. Diagram Alir Penelitian

\section{HASIL PENELITIAN DAN PEMBAHASAN}

Bahan baku campuran dari beton yang telah di buat terdiri dari semen, Tempurung kelapa, Serat ijuk, pasir, dan kerikil. Perlakuan beton yang telah dicetak dengan menggunakan cetakan kubus berukuran $(15 \mathrm{x} 15 \times 15) \mathrm{cm}^{3}$ dilakukan dengan proses perawatan (curing) dengan perendaman sampel dalam bak perendaman selama 28 hari. Untuk mengetahui karakteristik beton ringan tersebut maka perlu dilakukan pengukuran atau pengujian besaran fisis dan mekanis antara lain :daya Absorsi, porositas, dan kuat tekan.

\section{Porositas}

Gambar 2. Grafik Hubungan Porositas dan Komposisi abu sekam padi dan kulit kerang

Dari grafik di atas dapat dilihat bahwa dengan penambahan komposisi dari
Tempurung Kelapa dan Serat Ijuk maka porositas yang terjadi adalah semakin meningkat .

Dengan penambahan Tempurung Kelapa $6 \%$ ke $8 \%$ terjadi peningkata porositas sebanyak 4,5\%. Sedangkan pada beton normal porositasnya $2,5 \%$.

\section{Daya Serap Air}

Gambar 3. Grafik Hubungan antara daya serap air dengan komposisi abu sekam padi dan kulit kerang

Dari grafik di atas di peroleh daya serap air rata-rata terendah pada komposisi beton dengan penambahan Tempurung Kelapa $0 \%$ dan Serat Ijuk 0\%. Pada penelitian lakum daya serap air yang diperoleh pada kmposisi 5\% dan 8\% Tempurung Kelapa dan Serat Ijuk adalah $4,22 \%$.

\section{Kuat Tekan}

Gambar 4. Grafik hubungan kuat tekan terhadap abu sekam padi dan kulit kerang

Dari grafik di atas dapat dilihat bahwa ketika komposisi bahan mengalami peningkatan yang terjadi pada jumlah Tempurung Kelapa dan Serat Ijuk maka nilai uji tekannya mengalami penurunan kecil . Dari grafik juga dapat dilihat berturut-turut kuat tekan beton mengalami penurunan yang kecil.

\section{KESIMPULAN DAN SARAN Kesimpulan}

Kesimpulan dalam penelitian ini adalah sebagai berikut :

1. Semakin besar penambahan jumlah Tempurung Kelapa dan Serat 
Ijuk pada beton maka porositas dan penyerapan airnya mengalami penurunan yang kecil.

2. Hasil pengujian Porositas pada beton dengan variasi campuran Tempurung Kelapa 5\% ditambah Serat Ijuk 8\%, mengalami Peningkatan yaitu 9,89\%. Dan untuk Hasil Pengujian Absorsi Mengalami Peningkatan Pada variasi Tempurung Kelapa $4 \%$ ditambah Serat Ijuk 8\% yaitu 4,26\%, Untuk Pengujian Kuat Tekan Mengalami Penurunan Pada Campuran 4\% Tempurung Kelapa, 8\% Serat Ijuk yaitu kuat tekan 162,07 Kn.

\section{Saran}

1. Untuk melengkapi penelitian beton perlu ditambahkan kajian lebih lanjut meliputi : pengujian tahan api dan pengujian kuat tarik.

2. Pada pengujian porositas dan penyerapan air sebaiknya ditambahkan sampel beton normal sebagai pembandingnya.

3. Pada penelitian berikutnya diharapkan adanya tambahan variasi.

\section{DAFTAR PUSTAKA}

